\title{
EVALUASI PENEGERIAN MADRASAH
}

\section{The Evaluation of State Islamic School (Madrasah)}

\author{
Farida Hanun
}

\author{
Puslitbang Pendidikan Agama dan Keagamaan \\ Badan Litbang dan Diklat Kementerian Agama \\ Jl. Thamrin no 6 Jakarta Pusat. No tlpn/fax. 021.3920379 \\ Email: farida_ridwan@yahoo.com
}

Naskah diterima tanggal 27 Juli 2015. Naskah direvisi tanggal 27 Agustus 2015. Naskah disetujui tanggal 04 November 2015.

\begin{abstract}
Abstrak
Penelitian ini bertujuan untuk mengetahui kualitas penyelengaraan madrasah setelah dinegerikan. Penelitian evaluasi penegerian madrasah menggunakan metode survey pada Madrasah Negeri (MI, MTs dan MA) yang tersebar di 12 propinsi meliputi: Jabar, Jateng, DIY, Jatim, Banten, Sumsel, Riau, Babel, Lampung, Kalsel, Sulawesi Utara dan Bali. Hasil penelitian menunjukkan: 1) Telah terjadi perubahan sistem pengelolaan madrasah yang dinegerikan terkait dengan perekrutan, manajemen, pendidik dan tenaga kependidikan, sarana prasarana, dan kesiswaan; 2) Kendala dalam pengelolaan madrasah mencakup keterbatasan sarana prasarana, rendahnya anggaran dari pemerintah, dan rendahnya kompetensi guru; 3) Kebijakan penegerian madrasah membawa pengaruh terhadap meningkatnya prestasi akademik dan non akdemik siswa serta tingginya animo masyarakat; dan 4) Strategi pemerintah meningkatkan mutu madrasah dilakukan melalui perbaikan manajemen kurikulum, kesiswaan, sarana prasarana, pendidik dan tenaga kependidikan, keuangan dan hubungan masyarakat.
\end{abstract}

Kata kunci: evaluasi, penegerian, madrasah

\begin{abstract}
This study aims to identify the organization quality of madrasah (Islamic School) after becoming a state school. The Evaluation study of madrasah to become a state Islamic school used survey method in some State Islamic Schools (MI as the same level with elementary school, MTs as the same level with Junior High School and MA as the same level with Senior High School) located separately in 12 provinces such as: West Java, Central Java, Yogyakarta, East Java, Banten, South Sumatra, Riau, Babel, Lampung, South Kalimantan, North Sulawesi and Bali. The study showed:1) There have been changes in the management system of state Islamic school related to the recruitment, management, teachers and administration staff members, facilities, and students; 2) The constraints in madrasah management cover the lack of infrastructure, the low budget from the government, and the teachers' competence; 3) The policy of madrasah becoming state Islamic school had an impact on increasing the academic and non-academic achievement of the students as well the high interest of people; and 4) The strategy of government to improve the quality of madrasah was done through the improvement of curriculum management, student affairs, infrastructure, teachers and administration staff members, finance and public relation.
\end{abstract}

Keywords: evaluation, public, madrasah

\section{PENDAHULUAN}

$\mathrm{M}$ adrasah sebagai satuan pendidikan formal dalam binaan Menteri Agama yang menyelenggarakan pendidikan umum dan kejuruan dengan kekhasan agama Islam, eksistensinya telah mengalami transformasi secara gradual. Di awal kemerdekaan keberadaan madrasah sangat termajinalkan bahkan keberadaannya dianggap tidak ada, hingga akhirnya saat ini madrasah sudah menjadi sistem yang integratif dalam sistem pendidikan nasional sesuai dengan Undang-Undang No. 20 Tahun 2003. Keberadaan madrasah yang semula eksistensinya sangat lemah, kini semakin kuat dalam sistim pendidikan nasional. Semakin menguatnya eksistensi madrasah 
tidak dapat dipisahkan dari peran aktif Kementerian Agama yang telah memberikan pembinaan dalam penyelenggaraan pendidikan terkait peningkatan mutu pendidikan khususnya bidang manajerial, SDM, sarana prasarana.

Sebagai upaya peningkatan kualitas madrasah, peran Kementerian Agama tidak hanya sebatas memberikan bantuan dan bimbingan kepada madrasah, namun juga melakukan pengembangan status kelembagaan melalui program penegerian madrasah, baik madrasah swasta yang dikelola oleh pribadi maupun madrasah yang dikelola oleh organisasi-organisasi keislaman.

Selanjutnya jika melihat jumlah madrasah di seluruh Indonesia yang statusnya masih swasta sekitar 41.098 lembaga dan madrasah negeri sebanyak 3881 lembaga, mulai dari jenjang Madrasah Ibtidaiyah (1686) lembaga, Madrasah Tsanawyah (14.757) lembaga, dan Madrasah Aliyah (6.415) lembaga (Buku Statistik Pendidikan Islam Tahun Pelajaran 2011/2012. Direktorat Jenderal Pendidikan Islam Kementerian Agama).

Penegerian madrasah-madrasah swasta merupakan wujud dari program pemerintah yang bersungguh-sungguh memperhatikan peningkatan perluasan akses dan peningkatan mutu pendidikan. Dengan dinegerikannya madrasah swasta, implikasinya madrasah-madrasah menjadi milik negara, dibiayai negara secara bertahap, diatur dan dikelola pemerintah, karena menegerikan madrasah berarti menyerahkan asetnya kepada negara untuk dilanjutkan pengelolaannya oleh pemerintah.

Pemerintah melakukan penegerian madrasah dalam rangka meningkatkan pelayanan pendidikan, madrasah negeri sebagai motivator bagi madrasah lainnya, meningkatkan citra madrasah, merespon usulan masyarakat, dan menguatkan partisipasi masyarakat madrasah. Penegerian diperuntukkan terutama pada madrasah-madrasah di daerahdaerah terpencil, daerah pemekaran, daerah perbatasan antar Negara, daerah yang tidak memiliki madrasah negeri di kabupaten/kota, daerah yang memiliki madrasah filial dan daerah lain sesuai kebijakan Direktur Jenderal Pendis.

Hingga saat ini, Kementerian Agama belum mengetahui sejauh mana pelaksanaan program penegerian madrasah dan permasalahan yang dihadapi dalam pengelolaan madrasah yang sudah dinegerikan serta solusi pemecahannya. Dalam kerangka pemikiran itulah kiranya penelitian ini perlu dilakukan.

Berdasarkan latar belakang di atas, maka perumusan masalah penelitian adalah: 1) Apa saja motivasi yang melatarbelakangi penegerian madrasah? 2) Siapa tokoh yang berperan mendasari munculnya kebijakan penegerian madrasah? 3) Bagaimana dukungan masyarakat terhadap penegerian madrasah? 4) Bagaimana perubahan pengelolaan madrasah setelah penegerian? 5) Apakah dampak kebijakan penegerian terhadap mutu madrasah? 6) Apa kendala yang dihadapi dalam pengelolaan madrasah setelah dinegerikan? dan 7) Bagaimana Strategi peningkatan mutu madrasah.

\section{Tinjauan Pustaka \\ Pengertian evaluasi}

Madaus, Scriven dan Stufflebeam (1993:150) mendefinisikan evaluasi sebagai proses menggambarkan, memperoleh, dan menyajikan informasi yang berguna untuk merumuskan suatu alternatif keputusan. Sedangkan menurut Widoyoko (2012: 6), evaluasi merupakan proses yang sistematis dan berkelanjutan untuk mengumpulkan, mendeskripsikan, menginterpretasikan, dan menyajikan informasi tentang suatu program untuk dapat digunakan sebagai dasar membuat keputusan, menyusun kebijakan maupun menyusun program selanjutnya.

Menurut Arikunto (2007: 222) evaluasi adalah suatu proses yang dilakukan dalam rangka menentukan kebijakan dengan terlebih dahulu mempertimbangkan nilai-nilai positif dan keuntungan suatu program, serta mempertimbangkan proses serta teknik yang telah digunakan untuk melakukan suatu penelitian. Jaali dan Pudji (2010: 4) mengartikan evaluasi sebagai proses menilai sesuatu berdasarkan kriteria atau tujuan yang telah ditetapkan yang selanjutnya diikuti dengan pengambilan keputusan atas obyek yang dievaluasi.

Sedangkan Purwanti (2008: 6) berpendapat evaluasi adalah proses pemberian makna atau penetapan kualitas hasil pengukuran dengan cara membandingkan angka hasil pengukuran tersebut dengan kriteria tertentu. Menurut Gronlund (1976: 75) evaluasi adalah suatu pross yang sistematis untuk menentukan atau membuat keputusan sampai sejauh mana tujuan tercapai.

Dari beberapa definisi diatas disimpulkan evaluasi adalah keseluruhan proses yang sistematis dan berkelanjutan untuk membuat keputusan program berdasarkan sajian informasi yang telah terkumpul. Dengan demikian evaluasi tersebut merupakan proses yang sengaja direncanakan untuk memperoleh informasi atau data yang kemudian dicoba membuat keputusan. 
Adapun Evaluasi kebijakan adalah proses pengukuran dan pembandingan hasil nyata dari pelaksanaan kebijakan dengan hasil yang seharusnya dicapai menurut target dan standar atau rangkaian kegiatan membandingkan realisasi masukan (input), keluaran (output), dan hasil (outcome) terhadap rencana dan standar (Syaikhu Usman, 2014: 14).

Jenis evaluasi menurut tujuan: 1) Evaluasi proses yaitu mengkaji perjalanan penyampaian pelayanan (service delivery) dalam pelaksanaan kebijakan, 2) Evaluasi biaya-manfaat yaitu menilai biaya pelaksanaan relatif terhadap alternatif penggunaan sumberdaya dan manfaat, 3) Evaluasi dampak yaitu: melihat pengaruh yang diinginkan terhadap individu, rumahtangga, masyarakat dan lembaga.

Sedangkan jenis evaluasi menurut waktu pelaksanaan adalah: 1) Evaluasi formatif, dilaksanakan waktu pelaksanaan, bertujuan memperbaiki pelaksanaan, temuan utama berupa masalah dalam pelaksanaan, 2) Evaluasi Summatif, dilaksanakan setelah pelaksanaan selesai, tujuan menilai hasil pelaksanaan berupa capaian dari pelaksanaan.

Alasan mengapa perlu melakukan evaluasi kebijakan, dianatranya: a) berbagai kebijakan telah dilaksanakan, kadang memakan biaya besar, tetapi hasilnya seringkali tidak diketahui, b) alasan ekonomi: memperbaiki desain dan keefektifan kebijakan, realokasi sumberdaya pelaksanaan agar lebih efektif, c) alasan sosial: meningkatkan transparansi dan akuntabilitas, d) alasan politik, meningkatkan kredibilitas pengambilan keputusan.

Tahapan proses evaluasi:a) menentukan tujuan evaluasi: memperbaiki desain kebijakan, mengukur dampak, b) menyusun desain evaluasi yang kredibel: memerlukan indikator dan tolok ukur, menetapkan metode analisis dan kebutuhan data, menentukan jadwal pelaksanaan, c) mendiskusikan rencana evaluasi: penyandang dana, pelaksana kebijakan, ahli evaluasi yang kompeten, d) menentukan pelaku evaluasi: internal (pertentangan kepentingan), eksternal (keahlian, objektivitas, pengalaman), e) melaksanakan evaluasi: pengawasan kualitas data dan analisis, f) mendiseminasikan hasil evaluasi: bahasa sederhana dan mudah dimengerti, fokus pada temuan utama, adaptif terhadap umpan balik, g) menggunakan hasil evaluasi: tuntutan perubahan (bukan ancaman), pembelajaran organisasi, dasar kebijakan baru. (Syaikhu Usman, 2014:15).

\section{Penegerian madrasah}

Madrasah adalah satuan pendidikan formal dalam binaan Menteri Agama yang menyelenggarakan pendidikan umum dan kejuruan dengan kekhasan agama Islam yang mencakup Raudhatul Athfal, Madrasah Ibtidaiyah, Madrasah Tsanawiyah, Madrasah Aliyah, dan Madrasah Aliyah Kejuruan (PMA RI no 90 Tahun 2013 Tentang Penyelenggaraan Pendidikan Madrasah pasal 1).

Sedangkan penegerian madrasah merupakan sebuah proses peralihan status madrasah dari status swasta yang diselenggarakan oIeh yayasan/ masyarakat/badan hukum lainnya menjadi status negeri yang dikelola dan diatur oleh Kementerian Agama atas nama Pemerintah melalui mekanisme dan persyaratan yang telah ditetapkan (Petunjuk Pengajuan Proposal Penegerian Madrasah. 2009, Subdit Kelembagaan dan Kerjasama Direktorat Pendidikan Madrasah. Direktorat Jenderal Pendidikan Islam Kementerian Agama RI).

Kaitannya dengan penegerian madrasah, perhatian pemerintah untuk meningkatkan pembinaanmadrasah melaluipeningkatan status kelembagaan dilakukan dengan menegerikan sekolah rakyat Islam (SRI) menjadi madrasah ibtidaiyah negeri sebanyak 235 pada tahun 1962 . berdasarkan keputusan Menteri Agama 104 tahun 1962 madrasah tersebut semula berasal dari SRI yang diasuh oleh pemerintah daerah kemudian diserahkan kepada Kementeria Agama pada tahun 1959, yaitu: (1) 205 yang diasuh oleh pemerintah daerah Aceh; (2) 19 buah dari daerah keresidenan Lampung; (3) dari keresidenan Surakarta. Penegerian Madrasah Tsanawiyah swasta dan Madrasah Alaiyah swasta dilakukan pada tahun 1967 berdasarkan keputusan Menteri Agama No.80 Tahun 1967 dengan nama madrasah tsanawiyah agama islam negeri (MTsAIN) dan madrasah aliyah agama Islam negeri (MAAIN). Pada tahun 1970 keluar keputusan Menetri Agama No. 213 Tahun 1970 yang mengatur penghentian penegerian sekolah/madrasah swasta. Pada saat itu MIN telah berjumlah 358 buah, MTsAIN 182 buah, MAAIN 42 buah.

Pada tahun 1978 terjadi lagi restrukturisasi madrasah melalui keputusan Menteri Agama No. 15, 16, 17 Tahun 1978 yang berisi di samping pengubahan jumlah madrasah negeri juga perubahan nama madrasah yaitu MTs AIN menjadi MTsN dan MAAIN menjadi MAN. Pada tahun berikutnya terjadi lagi penegerian madrasah yang dimulai pada tahun 1991 dengan keputusan menteri Agama No. 137 tahun 1991, No.244 Tahun 1993, dan No. 151a Tahun 1995 ditambah lagi dengan terjadinya alih ungsi PGAN menjadi MAN dengan 
keputusan Menteri Agama No. 42 Tahun 1992 maka jumlah madrasah ini sampai dengan tahun 1999 adalah MIN 1435 buah, MTsN 1141 buah, dan MAN 553 buah.

Proses penegerian dilakukan terus oleh Kementerian Agama seiring dengan kebutuhan masyarakat, dan proses penegerian terhadap madrasah swasta terakhir kali di lakukan pada tahun 2009 dimana Kementerian Agama telah melakukan penegerian terhadap 416 madrasah, melalui tiga tahap. Tahap pertama penegerian madrasah Ibtidaiyah Negeri (MIN) sebanyak 46 buah, Madrasah Tsanawiyah Negeri (MTs) 70 buah dan Madrasah Aliyah 59 buah. Tahap ke dua, MIN sebanyak 54 buah, MTsN sebanyak 83 buah dan MAN sebanyak 41 buah. Tahap ke tiga, MIN sebanyak 19 buah, MTsN sebanyak 31 buah dan MAN sebanyak 13 buah. Namun Sejak tahun 2010 sampai sekarang tidak ada lagi kebijakan yang dikeluarkan oleh Kementerian agama berkaitan dengan penegerian bagi madrasah-madrasah swasta.

Proses penegerian madrasah dilakukan melalui pendekatan sebagai berikut: a) pemenuhan kebutuhan terhadap madrasah terutama di daerah perbatasan dan daerah terisolir, b) kuota kabupaten/kota yang belum memiliki madrasah negeri, c) optimalisasi pengelolaan madrasah, d) kesiapan madrasah dan dukungan masyarakat serta pemerintah setempat

Dalam melakukan penegrian madrasah, pemerintah membuat beberapa kriteria proses penegerian madrasah diantaranya: 1) kondisi daerah: perbatasan negara, pemekaran, terisolir, 2) kondisi madrasah: pengelola madrasah (yayasan berbadan hukum), ada tidaknya madrasah negeri, jarak madrasah negeri yang sederajat, 3) kondisi tanah dan kepemilikan tanah, 4) luas tanah, 5) kondisi bangunan, 6) sarana dan peralatan, 7) tenaga pendidik dan kependidikan, 8) tenaga pendukung, 9) siswa, 10) kurikulum, 11) prestasi, dan 12) dukungan pemda dan masyarakat.

Adapun tahapan-tahapan dalam proses penegerian madrasah, Pertama, sosialisasi Program Penegerian ke seluruh Pejabat Kanwil terkait untuk dilanjutkan ke Pejabat Kandepag. Kedua, Kandepag melalui Kanwil mengusulkan calon madrasah yang dinegerikan. Ketiga, tim teknis (Ditjen Pendis dan Ortala Sekjen) melakukan identifikasi terhadap data calon peserta penegerian. Keempat, verifikasi data calon peserta penegerian ke Lapangan. Kelima, tim teknis melakukan pengolahan data (skoring) berdasarkan panduan. Keenam, tim teknis melaporkan hasilnya ke Direktur jenderal Pendidikan Islam melalui Direktur Pendidikan Madrasah untuk diproses lebih lanjut oleh Biro Ortala Sekretarariat Jenderal ke Menpan.

\section{Penelitian yang relevan}

Penelitian evaluasi penegerian madrasah adalah penelitian evaluasi kebijakan pemerintah dan merupakan penelitian terbaru karena belum pernah ada penelitian yang mengevaluasi kebijakan pemerintah terkait penegerian madrasah. Pendapat ini dibenarkan oleh Kasubdit Kelembagaan Direktorat Pendidikan Madrasah Kementerian Agama, Dr. Rohmat Mulyana, bahwa Kementerian Agama belum pernah melakukan evaluasi terhadap madrasah-madrasah yang sudah dinegerikan. Dengan demikian penelitian ini terbaru, orisinil dan posisinya bukan replikasi dari penelitian lain.

\section{Kerangka berfikir}

Lembaga pendidikan madrasah adalah sebuah sistem yang terdiri dari komponen-komponen saling terkait satu sama lainnya. Komponen-komponen yang perlu diperhatikan dalam sistem pendidikan adalah masukan/input, proses, hasil belajar/output.

Dalam pelaksanaan program penegerian madrasah banyak komponen-komponen yang perlu dievaluasi dimana komponen tersebut mempengaruhi keberhasilan program penegerian madrasah baik masukan, proses, produk harus memenuhi kriteria yang telah ditentukan.

Pada evaluasi input, aspek yang dikaji meliputi tokoh pendiri madrasah, motivasi pendirian madrasah, prekrutan siswa, ketersediaan pendidik dan tenaga kependidikan, sarana prasarana, manajemen, dan dukungan masayarakat. Sedangkan evaluasi proses untuk menilai proses penegerian madrasah yang akan mengkaji motivasi penegerian, insiator, kriteria, prosedur penegerian yang harus dipenuhi dan pemenuhan 8 standar nasional pendidikan. Selanjutnya untuk evaluasi produk akan dilaksanakan mengenai berapa besar siswa memiliki prestasi unggul dan manfaat bagi guru dan kepala madrasah.

\section{METODE PENELITIAN}

Penelitian evaluasi ini menggunakan metode survei (Singarimbun, 1995: 4)dengan teknik statistik deskriptif. Lokasi penelitian ini di laksanakan pada Madrasah Negeri (MI, MTs dan MA) yang tersebar di 10 propinsi meliputi: Jawa Barat, Jawa Tengah, Jawa Timur, Banten, Sumatra Selatan, Riau, Babel, 
Lampung, Kalimantan Selatan, dan Bali. Lokasi ini merupakan daerah konsentrasi penyelenggaraan madrasah yang dinegerikan pada tahaun 2009 oleh Kementerian Agama.

Berkaitan dengan teknik pengambilan sampel, maka populasi dalam survei ini adalah seluruh satuan pendidikan pada madrasah negeri (MI, MTs dan MA) yang tersebar di seluruh Indonesia sebanyak 461 lembaga (MI, MTs dan MA yang sudah dinegerikan pada tahun 2009 sesuai data Direktorat Madrasah tahun 2009). Selanjutnya teknik penarikan sampel dalam penelitian ini menggunakan teknik random sampling. Dengan cara random dari 33 propinsi terpilih 10 propinsi sebanyak 93 madrasah yang sudah dinegerikan.

Adapun pengumpulan data dilakukan dengan menggunakan beberapa teknik, (1) kuesioner, (2) studi kepustakaan, dan (3) wawancara. Data kuantitatif yang terkumpul dari kuesioner dan untuk lebih memperdalam analisis data kuantitatif juga digunakan data kualitatif hasil wawancara dan studi kepustakaan.

\section{PEMBAHASAN}

\section{Motivasi yang Melatarbelakangi Penegerian Madrasah}

Secara moralitas dukungan dari masyarakat muslim di Indonesia sangat mendukung keberadaan MTs. Negeri untuk kemajuan dan perkembangan pendidikan Islam sekaligus sebagai tali kesinambungan jenjang pendidikan ke Aliyah Negeri. Kekawatiran masyarakat akan perkembangan anak-anaknya tidaklah berlebihan mengingat perkembangan pola-pola pergaulan remaja yang bersinggungan langsung dengan dunia luar dengan adat dan budaya yang berbeda (tidak bercorakkan budaya Islami) menjadikan alasan yang kuat bagi masyarakat. Disisi lain eksistensi keberdaan Madrasah swasta dari segi keuangan yang dimiliki yayasan-yayasan tidaklah terlalu besar sehingga menjadikan alasan kedua untuk segera menegerikan madrasah. Dari segi birokrasi pemerintahan pusat dan daerah mengeluarkan kebijakan penegerian tahun 2009 untuk peningkatan kualitas penyelenggaraan pendidikan di madrasah.

Survei menunjukkan motivasi terbanyak melakukan proses pendirian madrasah adalah untuk mendirikan lembaga pendidikan yang terjangkau masyarakat lemah 43 (38,75\%) madrasah, menyebarluaskan ilmu agama 32 (28,8\%), dan ingin mendirikan lembaga yang berkualitas 24 $(21,6 \%)$, pengabdian $12(10,8 \%)$. Motivasi untuk mencari keuntungan tidak menjadi latar belakang masyarakat menegerikan madrasah.
Setelah beberapa tahun madrasah didirikan, banyak madrasah swasta yang beralih status ke negeri. Adapun motivasi yang melatarbelakangi penegerian madrasah di daerah-daerah terungkap dari hasil wawancara dengan beberapa madrasah sasaran penelitian diantaranya: Muttaqin Kepala MAN Banjar Ciamis menjelaskan bahwa motivasi madrasah-madrasah melakukan proses penegerian karena ada sebagian yayasan tidak banyak berperan maksimal dalam pengembangan madrasah, keberadaan sumber daya pendidik dan tenaga kependidikan yang tidak memadai, sementara itu masyarakat lebih senang dan menghendaki adanya madrasah negeri.

Menurut Dudu Rohman Kasi Pendis Kemenag Tasikmalaya, kebijakan penegerian madrasah dilakukan karena masyarakat lebih berminat memilih madrasah negeri dibanding swasta, selain itu madrasah swasta sering mengalami kendala pada ketersediaan anggaran sehingga manajemen madrasah swasta kurang bagus dan tidak memenuhi standar serta konflik antar pengurus yayasan sering terjadi. Dengan dinegerikan diharapkan mendapat jaminan pembiayaan penyelenggaraan pendidikan dari pemerintah.

Sedangkan Mulyadi Kepala madrasah MIN Gondol Kab. Buleleng Bali mengungkapkan salah satu sebab madrasahnya dinegerikan karena belum ada satupun madrasah Ibtidaiyah berstatus negeri, sementara di Kabupaten Buleleng telah banyak berdiri madrasah swasta dan sekolah dasar Negeri. Lagi pula animo masyarakat tinggi untuk menyekolahkan anak-anaknya di madrasah negeri. Dengan kebijakan penegerian madraasah, masyarakat berharap penyelenggaraan pendidikan di madrasah akan lebih baik lagi terutama ketersedian fasilitas sarana pembelajaran.

\section{Tokoh Penegerian Madrasah}

Kalangan muslim merupakan masyarakat terbanyak di negara Indonesia. Oleh karena itu, perkembangan madrasah ke depan akan sangat cerah karena mendapat dukungan dari masyarakat luas dan agamis yang melibatkan semua kekuatan dari unsur pemerintah, organisasi keagamaan, para tokoh agama maupun masyarakat.

Hasil penelitian menunjukkan tokoh-tokoh pendiri madrasah mempunyai pekerjaan terbanyak sebagai sebagai PNS $36(32,4 \%)$ madrasah, karyawan swasta dan mubaligh masing-masing $32(28,8 \%)$ madrasah. TNI Polri $7(6,3 \%)$ dan buruh tani 4 $(3,6 \%)$ madrasah. Data menunjukkan bahwa PNS, karyawan swasta dan Mubaligh merupakan tokoh 
terbanyak yang berperan dalam proses pendirian madrasah.

Kaitannya dengan keragaman penghasil para tokoh pendiri, hasil survei menunjukkan rata-rata penghasilan tokoh pendiri per bulan tertinggi adalah di atas 4 juta sebanyak $15 \%$, antara 3 juta - 4 juta (24\%), 2 juta - 3 juta (23\%), 1 juta - 2 juta (19\%), di bawah 1 (18\%). Sebagai tokoh masyarakat dengan berbagai kesibukan dan tingkat ekonomi yang sederhana, mereka masih sempat memperhatikan kemajuan pendidikan madrasah di daerahnya. Adapun tokoh-tokoh yang berperan dalam proses pendirian madrasah di daerah-daerah terungkap bahwa mereka mempunyai pekerjaan dan penghasilan yang beragam.

Para inisiator pendirian madrasah berasal dari berbagai tokoh dengan jenjang pendidikan yang berbeda-beda. Kaitannya dengan keragaman jenjang pendidikan peneliti telah melakukan survei. Survei tentang jenjang pendidikan para tokokh pendiri madrasah dapat dilihat pada grafik diatas. Data menunjukkan jenjang pendidikan para tokoh pendiri madrasah terbanyak pada jenjang S1 44 (39,6\%), SMA/MA 37 (33,3\%), SMP/MTs 14 (12,6\%), SD/MI 11 (9,9\%) D3 sebanyak 5 (4,5\%) madrasah. Survei menjeskan jenjang pendidkan S1 dan SMA/MA merupakan jenjang pendidikan terbanyak para tokoh pendiri madrasah.

Selanjutnya kaitannya dengan tokok penegerian madarsah, pengusulan madrasahmadrasah swasta menjadi madrasah negeri merupakan keputusan dari berbagai tokoh masyarakat agar di daerah-daerah berdiri lembaga pendidikan formal Islam (madrasah) di bawah naungan pemerintah yang standar, berkualitas, memiliki daya saing tinggi dengan pendidikan formal lainnya.

Adapun tokoh-tokoh yang berperan dalam proses penegerian madrasah di daerah-daerah teruangkap dari hasil wawancara berikut: Menurut Dudung Kepala MAN Cibeurem bahwa tokoh yang berperan dalam penegerian MAN Cibeurem adalah tokoh pemuka agama, tokoh masyarakat, birokrasi pemerintah dan kepala MTsN dan swasta disekitar madrasah.

Dudu Rohman Kasi Pendidikan Madrasah Kab. Tasikmalaya menjelaskan tokoh yang berperan dalam proses penegerian madrasah di Tasik malaya adalah Kepala kemenag, Kasi Mapenda, yayasan dan masyarakat, sedangkan Husni Thamrin pengawas madrasah Kantor Kemenag Kab. Tasikmalaya mengatakan inisiator penegerian madrasah dianatranya kepala kemenag, kasi pendis dan tokoh masayarakat.
Kaitannya dengan jenjang pendidikan, Survei menunjukkan jenjang pendidikan kepala madarsah terbanyak pada jenjang S1 76 (6,5\%), SMA/MA 24 (21,6\%), SMP/MTs 5 (4,5\%), SD/MI 4 (3,5\%), D3 sebanyak $2(1,8 \%)$ madrasah. Survei menjeskan jenjang pendidkan S1 dan SMA/MA merupakan jenjang pendidikan terbanyak kepala madrasah.

Dari uraian di atas jelas terlihat adanya perbedaan jumlah jenjang pendidikan antara kepala madrasah swasta dengan kepala madrasah negeri. Dimana jenjang pendidikan SI pada madrasah swasta sebanyak 40\% namun sejak dinegerikan jumlah kepala madrasah yang jenjangnya S1 mencapai $68 \%$. Diharapkan dengan kondisi ini tingkat profesionalitas kepala madarsah negeri bisa lebih optimal lagi.

\section{Dukungan Masyarakat Terhadap Penegerian Madrasah}

Penegerian madrasah di daerah dan perkotaan pada umumnya merupakan keinginan dari yayasan. Namun, karena tidak selamanya yayasan bisa membantu madrasah terutama dalam hal sarana/ prasarana dan guru, demikian juga masyarakat, karena masyarakat masih memandang madrasah apalagi swasta menganggap sekolah kelas II, baik dari segi kualitas lulusannya, gurunya maupun sarananya. Oleh karena itu, banyak yayasan-yayasan yang menaungi madrasah swasta sepakat untuk segera dinegerikan. Bahkan segala fasilitas untuk persyaratan penegerian dengan cara ikhlas dan sukarela banyak yang membatu, baik materi maupun moril, materi dalam bentuk tenaga dan biaya, moril dalam bentuk dukungan doa dan perhatian.

Bentuk dukungan lain yang diberikan masyarakat ke madrasah adalah membentuk komite madrasah. Komite madrasah merupakan suatu badan yang mewadahi peran serta masyarakat dalam rangka meningkatkan mutu, pemerataan dan efisiensi pengelolaan pendidikan di satuan pendidikan. Badan ini bersifat mandiri, dan tidak mempunyai hubungan hirarkis dengan madrasah maupun lembaga perintah lainnya.

Bagaimana komite madrasah dibentuk dan dari unsur mana saja yang terlibat, survei telah dilakukan dan hasilnya menunjukkan sebagian besar komite madrasah dibentuk melalui keterlibatan unsur-unsur secara lengkap mulai dari unsur kepala madrasah, yayasan, orang tua dan tokoh masyarakat sebanyak 71 (64\%) madrasah.

Dalam Pasal 196 PP No. 17 Tahun 2010 disebutkan: komite madrasah berfungsi dalam peningkatan mutu pelayanan pendidikan dengan 
memberikan pertimbangan, arahan dan dukungan tenaga, sarana dan prasarana, serta pengawasan pendidikan pada tingkat satuan pendidikan. Kaitannya dengan sejauhmana komite madrasah telah melakukan fungsi kontrol/pengawasan terhadap madrasah, telah dilakukan survei. Survei menunjukkan komite mengontrol dengan maksimal 30 (27\%), komite dapat mengontrol tapi kurang maksimal 49 (44\%), komite dapat mengontrol tapi tidak maksimal 26(23\%), ko ite tidak dapat mengontrol 3 (3\%) dan menjawab tidak tahu 3 (3\%). Hasil survei mengisyaratkan bahwa komite madrasah belum maksimal melakukan fungsi kontrol. Dampaknya adalah komite tidak dapat meberikan masukan kepada madrasah untuk menerapkan berbagai kebijakna pendidikan yang tepat dan kena sasaran.

\section{Perubahan Pengelolaan Madrasah Setelah Penegerian}

Banyak tokoh masyarakat yang terlibat dalam penyelenggraan madrasah melakukan proses penegerian madrasah dengan maksud agar adanya peningkatan kualitas penyelenggraan pendidikan di madrasah. Dalam rangka mengetahui perubahan yang terjadi pada madrasah yang sudah dinegerikan, maka dalam penelitian ini telah dilakukan perhitungan dengan melihat perubahan nilai pada komponen: perekrutan, manajemen, dukungan masyarakat, pendidik dan tenaga kependidikan, sarana prasarana dan kesiswaan.

Dilihat dari aspek perekrutan, pengelolaan madrasah yang sudah di negerikan biasanya akan mengalami perubahan dalam penyelenggaraannya, termasuk perubahan dalam merekrut siswa, guru dan kepala madrasah. Hasil survei menunjukkan pengelolaan madrasah kaitannya dalam aspek perekrutan siswa sebelum dinegerikan barada pada nilai 52,19 dengan katagori kurang, namun setelah dinegerikan terilihat ada peningkatan nilai sebesar 61,8 dengan katagori cukup. Madrasah negeri kalau ingin mengembangkan Madrasah menjadi yang berprestasi, harus memulainya dengan mengembangkan faktor kuncinya, yaitu sumberdaya manusia meliputi kepala Madrasah, guru-guru, siswa. Peningkatan kualitas kepala madrasah dimulai dari cara perekrutan kepala Madrasah yang harus dilakukan melalui uji kompetensi kepala madrasah sehingga akan melahirkan pemimpin pendidikan yang berkualitas. Selain itu, pada komponen perekrutan guru, yang semula di lakukan melalui jalur tanpa tes ketika masih status madrasah sawsta, maka setelah dinegerikan guru-guru yang akan mengajar harus melalui sistem seleksi tes. Hal ini dilakukan agar guru-guru di madrasah negeri memiliki kemampuan tinggi dan handal dalam menggunakan berbagai metode dan pendekatan pembelajaran.

Begitupuladengankomponensiswa. Madrasah negeri agar menjadi center for excellence anak-anak terbaik, maka input siswa yang masuk haruslah melalui proses seleksi yang ketat dengan berbagai kententuan lainnya. Selain seleksi bidang akademis, juga diberikan persyaratan lain sesuai tujuan yang ingin dicapai maadrasah. Misalkan tes IQ, prestasi belajar dari jenjang pendidikan sebelumnya, tes kesehatan, kemampuan membaca al-Qur'an, wawasan keagamaan, dll.

Pada aspek manajemen, hasil survei menunjukkan pengelolaan madrasah dalam aspek manajemen madrasah sebelum dinegerikan barada pada nilai 80,1 dengan katagori baik, dan setelah dinegerikan nilainya 86,5 katagori amat baik. Terilihat ada peningkatan nilai dan katagori. Madrasah yang sudah dinegerikan biasanya akan mengalami perubahan pengelolaan madrasah dengan sistem manajemen yang modern, transparan dan demokratis melalui ketersediaan struktur organisasi, program kerja yang tertata, adanya Rencana Kegiatan dan Anggaran Madrasah (RKAM) yang jelas, tenaga pendidikan yang professional, kelengkapan sarana dan prasarana, adanya kurikulum yang sesuai dengan kebutuhan masyarakat dan tantangan dunia modern. Selain itu madrasah juga memberikan perhatian untuk senantiasa meningkatkan kualitas, mengembangkan inovas dan kreatifitas, membangun jaringan kerjasama (networking).

Untuk terciptanya lingkungan belajar yang kondusif baik lingkungan fisik maupun sosial psikologis, diperlukan SDM pimpinan dan tenaga pendidik yang handal. Dari SDM tersebut, yang perlu diprioritaskan pengembangannya adalah kepala Madrasahnya karena dialah yang diharapkan akan menjadi motor reformasi (perubahan) manajemen Madrasah tersebut. Pemerintah harus mengembangkan para kepala Madrasah negeri menjadi kepala Madrasah yang berjiwa pemimpin, bukan sekedar manajer.

Selanjutnya pada aspek dukungan masyarakat, hasil survei menunjukkan pengelolaan madrasah tentang aspek dukungan masyarakat terhadap penyelenggaraan pendidikan sebelum dinegerikan barada pada nilai 79,5 dengan katagori baik, namun setelah dinegerikan nilainya 85,6 katagori amat baik. Terilihat ada peningkatan. 
Madrasah swasta untuk memenuhi kebutuhan operasional madrasah memerlukan banyak dana yang bersumber dari yayasan dan para donatur. Namun sejak di negerikan bantuan masyarakat masih diperlukan juga karena pemerintah tidak bisa memenuhi $100 \%$ dana operasional madrasah negeri. Oleh karena itu, selain dana dari pemerintah, madrasah bisa bekerja sama dengan komite madrasah dalam upaya menggalang dana untuk pengembangan madrasah. Di lapangan terlihat adanya dukungan yang kuat dari orang tua dan masyarakat sekitar, yang bisa diartikan sebagai kerelaan mereka untuk mendukung pengembangan madrasah itu dengan uang mereka. Dana memang diperlukan untuk membeli fasilitas belajar yang baik, untuk membayar gaji guru honor bidang studi, untuk meningkatkan kesejahteraan guru sehingga motivasi kerja mereka juga meningkat, dan untuk membiayai penataran guru sehingga mereka dapat mengajar lebih baik. Akan tetapi, dana itu dapat diusahakan jika fihak-fihak yang mempunyai dana dapat diyakinkan akan perlunya dana tersebut diberikan kepada Madrasah negeri yang memerlukan dana.

Selain dukungan dari komite, madrasah juga harus mendapat dukungan dari pemerintah khususnya Direktorat madrasah (pusat) dan Kankemenag Kab/kota. Hasil survei ini menunjukkan hubungan madrasah yang dinegerikan dengan pemerintah berjalan sangat lancar sebanyak 55,9\% madrasah, lancar 34,2\% madrasah, cukup lancar 5,4\% madrasah, kurang lancar 2,7\% madrasah, dan tidak lancar $1,8 \%$. Data ini menjelaskan setelah dinegerikan hubungan dengan pemerintah/kankemenag semakin lancar, hal ini akan memberikan dampak positip pada kualitas penyelenggaraan madrasah.

Pada aspek pendidik dan tenaga kependidikan, hasil survei menunjukkan pengelolaan madrasah dalam aspek pendidik dan tenaga kependidikan sebelum dinegerikan barada pada nilai 82,6 dengan katagori baik, namun setelah dinegerikan nilainya 94,2 katagori amat baik Terilihat ada peningkatan tajam. Ketersediaan pendidik dan tenaga kependidikan madrasah negeri biasanya lebih baik dari madrasah swasta karena sistem perekrutannya melalui tes tulis dan wawancara, sehingga kualitasnya lebih unggul. Kualifikasi jenjang pendidikan pendidik banyak yang sudah S1 dan segi kompetensinya sebagian besar sudah sesuai dengan latar belakang pendidikan bahkan banyak juga yang sudah tersertifikasi. Para pendidik Madrasah negeri adalah orang yang bertanggung jawab memberikan bantuan belajar dan bimbingan kepada peserta didik dalam perkembangan jasmani dan rohani. Tanggung jawab ini hanya bisa dilakukan oleh pendidik profesional yang mempunyai dedikasi, kejujuran, tekun, disiplin, menguasai materi pelajaran, metode mengajar, maupun komitmen dalam melaksanakan tugas.

Pada aspek keberadaan sarana prasarana madrasah, hasil survei menunjukkan sebelum dinegerikan barada pada nilai 60,7 katagori cukup, namun setelah dinegerikan nilainya 70,8 dengan katagori baik. Terilihat ada sedikit peningkatan. Idealnya sebuah madrasah yang sudah dinegerikan memiliki sarana dan prasarana yang menunjang kebutuhan belajar siswa serta menyalurkan minat dan bakatnya (kurikuler dan ekstrakurikuler) yang terdiri dari: ruang kelas, ruang kepala sekolah, ruang guru, ruang tata usaha, mushola, ruang kesehatan, perpustakaan, gudang dan kamar mandi. Kondisi tanah, ruang, dan gedung dibuat senyaman mungkin untuk mendukung kegiatan belajar mengajar selain itu ruang kelas harus disesuaikan dengan jumlah peserta didik dan didukung dengan perabotan dan perlengkapan yang menunjang kelancaran proses pembelajaran. Diharapkan dengan fasilitas yang baik secara otomatis akan memudahkan mereka meningkatkan kualitas pendidikan madrasahnya. Namun hasil survei menunjukkan, keberadaan sarana Laboratorium IPA pada madrasah yang sudah dinegerikan masih ada sekitar $43 \%$ madarsah tidak memiliki Laboratorium IPA. Kondisi yang memprihatinkan. Kondisi ini berbeda dengan kondisi ruang kepala madrasah, dimana keberadaan ruang kepala sebelum madrasah dinegerikan masih ada $23 \%$ yang tidak memiliki ruang kepala madrasah, tapi setelah dinegerikan semua madrasah negeri sudah memiliki ruang kepala madrasah.

Selanjutnya pada aspek kesiswaan, hasil survei menunjukkan pengelolaan madrasah kaitannya dalam aspek kesiswaan sebelum dinegerikan barada pada nilai 73,6 dengan katagori baik, namun setelah dinegerikan nilainya bertambah menjadi 77,7 dengan katagori baik. Terilihat ada peningkatan. Peserta didik madrasah adalah individu yang sedang membentuk jati dirinya melalui proses pembinaan agar menjadi insan yang beriman dan bertaqwa. Mereka belajar di madrasah untuk mendapatkan ilmu baik dari ubudiyah dan muamalah. Madrasah negeri harus menghasilkan lulusan yang unggul. Keunggulan lulusan tidak hanya ditentukan oleh nilai ujian yang tinggi. Indikasi lulusan yang unggul ini baru dapat diketahui setelah yang bersangkutan memasuki dunia kerja dan terlibat aktif dalam 
kehidupan bermasyarakat. Kemampuan lulusan yang dihasilkan dirasa unggul, bila mereka telah mampu mengembangkan potensi intelektual, potensi emosional, dan potensi spiritualnya dimana mereka berada. Oleh karena itu, kondisi pembelajaran di kelas harus memberikan pengalaman siswa yang medorong tumbuhnya etos kerja siswa, membangun motivasi untuk berprestasi dan menunmbuhkan kepuasan kerja (Supiana, 2008:284).

Hasil survei terkait dengan angka lulus yang melanjutkan ke jenjang berikutnya, menunjukkan adanya peningkatan nilai yaitu dari 268 (sebelum dinegerikan) menjadi 455 setelah dinegerikan, selisihnya 187. Artinya jumlah siswa yang melanjutkan ke perguruan tinggi bertambah banyak setelah madrasah dinegerikan. Selain itu nilai ketuntasan belajar siswa juga mengalami kenaikan, nilai perubahan dari 353 (sebelum dinegerikan) menjadi 434 setelah dinegerikan, selisihnya 187. Artinya nilai ketuntasan bebelajar mata pelajaran IPA dan IPS bertambah naik setelah madrasah dinegerikan. Sedangkan angka siswa yang lulus juga terjadi perubahan nilai dari 441 (sebelum dinegerikan) menjadi 511 setelah dinegerikan, selisihnya 70. Artinya jumlah siswa yang lulus bertambah naik setelah madrasah dinegerikan.

Adapun tentang jumlah pendaftar dibandingkan dengan daya tampung siswa baru, survei menujukkan terjadi kenaikan nilai dari 351 (sebelum dinegerikan) menjadi 406 setelah dinegerikan, selisihnya 55. Artinya jumlah siswa yang mendaftar dibandingkan dengan daya tampung yang tersedia bertambah naik setelah madrasah dinegerikan. Pada ahirnya, keunggulan sebuah madrasah negeri akan sangat ditentukan oleh keberhasilan peserta didik (output dan outcome) yang memiliki prestasi yang membanggakan. Dalam konteks keberhasilan madrasah, maka keberhasilan tersebut tidak saja diukur dari nilai akademik yang tinggi (NEM), tetapi juga harus dilihat dari perilaku yang Islami (akhlaqul karimah).

\section{Dampak Kebijakan Penegerian Madraasah}

Bagi madrasah swasta yang anggaran operasional kegiatan madrasah agak terbatas, maka kebijakan penegerian madrasah yang dilakukan oleh pemerintah sangat tepat, karena bagi madrasah yang sudah dinegerikan secara otomatis pembiayaan guru, sarana, kegiatan ekstrakurikuler dan optimalisasi kelengkapan laboratorium akan dipenuhi oleh pemerintah. Kondisi ini akan berpengaruh terhadap peningkatan kualitas siswa baik pada bidang akademik maupun non akademik (ekstrakurikuler). Pemerintah melakukan proses penegerian terhadap madrasah swasta dengan maksud agar terjadinya peningkatan kualitas pembelajaran melalui pemenuhan delapan standar nasional pendidikan (SNP).

Prestasi bidang akademik pada madrasahmadrasah yang sudah dinegerikan dari hasil penelitian menunjukkan peningkatan. Proses penegerian diharapkan akan menaikkan nilai UN pada semua mata pelajaran. Jika ada data mata pelajaran UN yang mengalami penurunan, mungkin ada beberapa faktor yang menyebabkannya. Hasil wawancara dengan Yusuf efendy Pengawas Kab. Bojonegoro Jawa Timur bulan Agustus 2014 terungkap bahwa kualitas siswa madrasah yang sudah dinegerikan khususnya di madrasah kab Bojonegoro mengalami peningkatan, karena meningkatnya ketersediaan sarana, kompetensi guru, kualitas input. Adapun madrasah yang sudah dinegerikan tapi masih rendah UN nya, mungkin disebabkan salah satunya SDM siswa yang rendah dimana proses perekrutan siswa madrasah negeri masih menggunakan sistem penerimaan siswa dengan cara tidak pakai tes, terutama di daerahdaerah pedalaman. Kalau ada sebagian madrasah menggunakan tes dalam penerimaan siswa baru, itu juga menggunakan syarat kelulusan nilai tes dengan angka yang rendah.

Menurut peneliti, banyak faktor yang mempengaruhi penurunan hasil nilai Ujian Nasional (UN) beberapa mata pelajaran pada jenjang MTS dan MA yang sudah dinegerikan, sehingga belum mendukung efektifnya kegiatan pembelajaran di madrasah, seperti kegiatan pembelajaran siswa yang pasif karena penggunaan metode pembelajaran yang masih konvensional, masih banyak guru yang kurang kompetensinya serta kurang memadainya sarana labaratorium baik IPA dan komputer. Hal lain yang mungkin menjadi faktor penurunan perolehan nilai hasil belajar adalah kondisi kegiatan pembelajaran yang tidak merangsang ketertarikan siswa dalam belajar baik dari kognitif, afektif, maupun psikomotorik, ditambah lagi penggunaan strategi pembelajaran yang kurang tepat serta kelengkapan sarana prasarana pembelajaran. Faktor eksternal diluar kelas juga harus diperhatikan, misalnya sejauh mana peranan pengawas melakukan bimbingan terhadap madrasah-madrasah yang dibinanya dan juga kemampuan kepala madrasah dalam memimpin madrasah untuk menciptakan iklim pembelajaran yang kondusif.

Sedangkan prestasi non akademik pada beberapa madrasah yang sudah dinegerikan, hasil 
penelitian menunjukkan grafik yang meningkat. Sejak madrasah-madrasah di negerikan tahun 2009, maka saat ini prestasi non akademik siswa madrasah mengalami peningkatan. Keberhasilan akan meningkatnya prestasi non akademik siswa, ditentukan pula dengan penempatan posisi kepala madrasah, paling tidak pemerintah akan menempatkan kepala madrasah yang lebih berkualitas dan pandai memanaj organisasi Madrasah. Siswa sering mendapatkan prestasi di dalam mengikuti lomba non akademik, keberhasilan ini berkat adanya program ekstrakurikuler untuk siswa sesuai dengan minat bakat yang dimilikinya, guru, masyarakat diajak untuk dapat memberikan bimbingan penambahan keahlian bagi siswa.

Lebih detailnya gambaran dampak penegerian terhadap output siswa madrasah di daerahdaerah terangkum dalam wawancara di bawah ini. Hasil wawancara dengan Mulyadi Kepala MIN Gondol Bali November 2014 terungkap bahwa sejak madrasahnya dinegerikan tahun 2009, peningkatan prestasi akademik/non akademik siswa Madrasahnya mengalami peningkatan signifikan antara lain: juara 2 lomba cerdas cermat agama SD/MI tingkat kabupaten 2014, juara 3 olimpiade MIPABA, juara perlombaan MTQ dan juara festival Marching Band serta kompetisi Matematika dan lain lain.

Kondisi tidak jauh beda dengan MTsN Jembarana (wawancara dengan Sarasmawantyo Kepala madrasah, November 2014), sejak madrasahnya dinegerikan telah menjuarai lombalomba dan kompetisi diberbagai even, adanya guru berprestasi tingkat kabupaten, penambahan sarana dan prasarana, seperti, pembangunan RKB, perpustakaan, perlengkapan alat perkantoran, adanyanya penigkatan kedisiplin dari guru dan siswa, adanya program Tuntas Baca Alquran, Hafalan juz Amma, dan sholat dzuhur berjamaah, aktifnya kegiatan UKS, kegiatan ekstra kurikuler, kegiatan bakti sosial di masyarakat. Paparan di atas menunjukkan prestasi non akademik madrasah yang sudah dinegerikan mengalami peningkatan yang signifikan.

\section{Pengaruh Perubahan Status Penegerian Madrasah Terhadap Keberadaan Madrasah Swasta Disekitarnya}

Perubahan status madrasah yang sudah menjadi negeri memberi pengaruh positip dalam peningkatan mutu madrasah yang dinegerikan. Namun bagi madrasah swasta disekitarnya ada kehawatiran jika ada salah satu madrasah swasta dinegerikan oleh pemerintah, maka hal ini akan mempengaruhi hidup matinya keberadaan madrasah swasta di sekitarnya.

Gambaran tentang keberadaan madrasah negeri, apakah akan mempengaruhi hidup matinya keberadaan madrasah swasta di sekitarnya, dapat dilihatdarihasilwawancaraberikutini.MenurutSaras Mawantyo Kepala MTsN Jembrana Bali (wawancara bulan November 2014), keberadaan umat muslim dikawasan kami lebih memilih madrasah dari pada sekolah umum karena keberadaan kami di daerah minoritas, sehingga siswa yang masuk di madrasah cukup banyak baik di negeri maupun swasta yang telah memiliki pengelolaan yang baik. Mengenai keberadaan MTs Negeri Jembrana, sering turut serta dalam pembinaan pengembangan madrasah swasta, sehingga keberadaan MTsN Jembrana sangat membantu madrasah swasta dan bukan menghawatirkan.

Menurut Syahrudin, Kasi Pendis Kab. Rokan Hulu Riau (wawancara Agustus 2014) agar keberadaan MTs negeri tidak berpengaruh negatif terhadap hidup matinya madrasah swasta, maka jarak lokasi madrasah negeri dengan swasta harus agak jauh dan tidak terlampu saling berdekatan. Ditambahkan pula oleh Patahul Bari (wawancara bulan November 2014) menjelaskan keberadaan MAN Mendoyo Jembrana tidak berdampak negatif terhadap madrasah swasta disekitarnya, karena masih banyak siswa yang diterima di madrasah swasta dan hubungan MAN Mendoyo dengan madrasah swasta sekitarnya sangat harmonis terbukti dengan diadakannya kegiatan Kelompok Kerja Madrasah (KKM).

Dari uraian di atas terungkap bahwa keberadaan madrasah negeri tidak akan mematikan kehidupan madrasah swasta melainkan sebaliknya madrasah swasta akan menjadi binaan madrasah negeri sehingga akan memberi peluang madrasah swasta menjadi lebih berkembang.

\section{Animo Masyarakat}

Kaitannya dengan animo masyarkat yang ingin masuk ke madrasah setelah dinegerikan semakin besar karena Madrasah Negeri Membebaskan biaya SPP, PBM lebih baik dari sebelumnya, sekolah gratis tanpa adanya pungutan biaya apapun, kegiatankegiatan kesiswaan semakin tinggi aktivitasnya, pembinaan siswa dan kegiatan ekstra semakin maksimal.

Lebih detailnya gambaran animo masyarakat terhadap madarsah yang sudah dinegerikan di daerah-daerah terangkum dalam wawancara di 
bawah ini. Menurut Syahrudin Kasi Pendis Rokan Hulu Riau (wawancara bulan Agustus 2014), "Sejak madrasah-madrasah dinegerikan animo masyarakat masuk madrasah bertambah banyak. Hal ini dikarenakan madrasah negeri dianggap oleh masyarakat memilki guru-guru yang kompeten, biaya sekolah lebih murah, fasilitas belajar lebih baik, dan jaminan lulusannya untuk dapat memilih sekolah yang lebih baik sesuai keinginan."

Sedangkan Mahyuni Kasi Pendidikan Madrasah Kota Banjarmasin (wawancara bulan Agustus 2014), menjelaskan Animo masyarakat masuk madrasah negeri menjadi lebih banyak karena orangtua atau masyarakat di sekitar Banjarmasin akan bangga bila anaknya bisa sekolah di madrasah negeri. Sedangkan Agus Subagio pengawas Kab. Jembarana Bali menjelaskan berubahnya madrasah swasta menjadi negeri berpengaruh terhadap banyaknya animo masyarakat yang masuk, karena masyarakat menilai Madrasah Aliyah Negeri mempunyai keunggulan terutama keberadaan tenaga pendidik yang berkualitas dan ditunjang pula dengan pengelolaan manajerial yang lebih baik.

Dengan demikian hasil penelitian menunjukkan proses penegerian madrasah berdampak pada meningkatkan animo masyarakat masuk madrasah.

\section{Kendala-kendala yang Dihadapi Madrasah Setelah Penegerian}

Setiap madrasah yang sudah dinegerikan pasti menginginkan madrasahnya meningkat prestasinya seiring dengan ikut campurnya pemerintah memberikan biaya operasional. Namun kondisi di lapangan, pihak madrasah banyak menghadapi kendala-kendala dalam pengelolaanya.

Hasil penelitian menunjukkan sebagian besar kendala yang dihadapi madrasah yang sudah dinegerika diantaranya sarana prasarana berupa jumlah Ruang kelas belum memenuhi standar, dan tidak sesuai dengan jumlah. Ruang Kerja Baru (RKB) yang ada masih mangkrak (belum selesai pembangunanya karena anggaran tidak cukup). Gedung perpustakaan yang ada masih kurang berfungsi (jarang dikunjungi siswa karena ketidaklengkapan buku-buku yang ada). Ruang kepala, guru, dan TU tidak memenuhi standar alias seadanya saja. Terakhir ruang-ruang penunjang kurang terpenuhi diantaranya ruang praktek, ruang ibadah, ruang UKS, ruang pertemuan/aula, ruang laboratorium.

Kendala berikutnya tenaga pendidik, jika dilihat dari kualifikasi dan kompetensi tenaga pendidik cukup memadai dan ijazah sesuai dengan kualifikasi mata pelajaran yang diampu namun masih kekurangan guru PNS, tenaga pendidik dan kependidikan yang ada masih banyak bersatus honorer. Selain itu, rendahnya anggaran dikarenakan rencana kebutuhan dan anggaran yang ada belum memadai. Salah satu penyebab rendahnya prestasi siswa di tingkat nasional dikarenakan masih minimya sarana-prasarana, dan anggaran yang dapat menunjang prestasi siswa untuk mampu bersaing di tingkat nasional. Rendahnya prestasi siswa di tingkat nasional dikarenakan masih minimya sarana-prasarana, dan anggaran yang dapat menunjang prestasi siswa untuk mampu bersaing di tingkat nasional.

\section{Strategi Peningkatan Mutu Madrasah}

Dalam rangka peningkatan mutu pengelolaan madrasah yang sudah dinegerikan bisa dilakukan beragam cara. Pemerintah harus memikirkan strategi apa yang bisa dilakukan ke depan oleh madrasah agar mutu pengelolaan meningkat. Lebih rincinya paparan tentang strategi ke depan untuk memajukan madrasah yang sudah dinegerikan terangkum dalam wawancara di berikut ini. Mahyuni Kasi Pendidikan Madrasah Kota Banjarmasin menjelaskan strategi ke depan agar proses penegerian berjalan dengan baik, maka perlu pemebnahan aset madarsah, terutama sertifikat tanah agar semua seragam dan diatas namakan Kementerian Agama, namun biasanya tidak semua yayasan mau menyerahkan asetnya ke negara.

Menurut Surja Kasi Pendis Kankemenag Jembrana Bali (wawancara bulan November 2014), strategi peningkatan mutu madrasah bisa dilakukan melalui perekrutan personil yang kompeten dibidangnya, memperbaiki kualitas sarana prasarana, menerapkan prinsip keterbukaan, dan promosi yang lebih gencar tentang keberadaan madrasah negeri.

Sumardi, pejabat Kankemenag Kab. Empat Lawang Lampung (wawancara bulan Agustus 2014), menjelaskan strategi peningkatan mutu madarsah yang sudah dinegerikan meliputi: 1) pengingkatan pelayanan pada masyarakat, 2) mengedepankan pendidikan keagamaan dengan tidak mengesampingkan pendidikan umum, sehingga berjalan bersama sama, 3) mengikutsertakan masyarata ikut aktif mensukseskan program pendidikan bagi anak-anak bangsa, dan 4) mengingatkan pada masyarakat untuk sama-sama menjaga aset pemerintah dengan baik.

Dari paparan di atas menunjukkan bahwa strategi yang bisa dilakukan untuk peningkatan 
mutu pengelolaan madrasah beragam caranya diantaranya:1) meningkatkan Sarana dan prasarana yang sesuai dengan standar pelayanan maksimal untuk menunjang program-program madrasah, 2) meningkatkan kesejahteraan tenaga pendidik dan kependidikan yang masih honorer untuk meningkatkan kualitas pembelajaran, 3) melengkapi alat-alat perkantoran untuk menunjang tugas pokok dan fungsi, 4) mengadakan programprogram untuk meningkatkan prestasi madrasah, siswa, guru, dan kepala madrasah, 5) meningkatkan pelayanan kepada masyarakat, dan 6) meningkatkan pembinaan dibidang akademik maupun non akademik agar dapat bersaing ditingkat nasional.

\section{PENUTUP}

Latarbelakang penegerian madrasah yang utama untuk menjangkau pendidikan pada kalangan masyarakat lemah dan meningkatkan kualitas pendidikan. Banyak tokoh yang mendukung proses penegerian madrasah diantaranya: unsur pimpinan Kemenag kab/kota dan tokoh masyarakat (pegawai swasta dan mubalig). Dukungan masyarakat dalam penegerian madrasah berupa dana dan tenaga. Sejak madrasah dinegerikan telah terjadi perubahan sistem pengelolaan madrasah terkait dengan perekrutan, manajemen, pendidik dan tenaga kependidikan, sarana prasarana, dan kesiswaan. Namun masih ada kendala dalam pengelolaan madrasah mencakup keterbatasan sarana prasarana, rendahnya anggaran dari pemerintah, dan kurangnya kompetensi guru.

Di sisi lain ternyata kebijakan pemerintah melakukan penegerian madrasah membawa pengaruh terhadap meningkatnya prestasi akademik dan non akdemik siswa serta tingginya animo masyarakat. Seiring dengan itu maka pemerintah perlu meningkatkan mutu madrasah dilakukan melalui perbaikan manajemen kurikulum, kesiswaan, sarana prasarana, pendidik dan tenaga kependidikan, keuangan dan hubungan masyarakat.

Dengan adanya perubahan status madrasah menjadi negeri, masyarakat akan merasakan langsung dari perubahan status tersebut terutama dari aspek penjaminan mutu pendidikan yang terstandarkan. Oleh karena itu, pemerintah perlu mengupayakan menghidupkan kembali regulasi tentang penegerian madrasah. Pemerintah perlu memperhatikan proses pengalihan kepemilikan asset pihak swasta ke pihak pemerintah, sesuai dengan undang-undang yang berlaku dan ke depan perlu menyelenggarakan program-program pembinaan dan peranan terhadap madrasah yang sudah dinegerikan secara berkesinambungan oleh: Direktorat Madrasah/Pusat, Kantor Wilayah Kementerian Agama Provinsi, dan Kemenag tingkat Kabupaten/Kota.

\section{UCAPAN TERIMA KASIH}

Terima kasih kepada Kepala Puslitbang Pendidikan Agama dan Keagamaan Badan Litbang dan Diklat yang telah memberi kesempatan kepada penulis untuk meneliti, dan para kepala madrasah termasuk juga seluruh pengawas yang turut membantu memberikan data dan informasi, juga kepada Redaktur Jurnal Al Qalam atas termuatnya tulisan ini, semoga tulisan ini memberikan wawasan dalam pendidikan agama di Indonesia.

\section{DAFTAR PUSTAKA}

Arikunto, Suharsimi. 2007. Manajemen Penelitian. Jakarta: PT Rineka Cipta.

Buku Statistik Pendidikan Islam Tahun Pelajaran 2011/2012. Direktorat Jenderal Pendidikan Islam Kementerian Agama.

Djaali dan Pudji Mulyono. 2010. Penelitian dan Evaluasi Pendidikan. Jakarta: Program Pasca Sarjana Univ. Negeri Jakarta.

Gronlund, N. E. 1976. Improving Marking and Reporting in Classroom Instruction. New York: Macmillang Publishing Co., Inc.

Madaus G.F, Scriven, M.S dan Stufflebeam. 1993. Evaluation Models viewpoints an educational and human services evaluation. Boston: Kluwer-Nijhoff Publishing.

Peraturan Menteri Agama RI no 90 Tahun 2013 Tentang Penyelenggaraan Pendidikan Madrasah.

Petunjuk Pengajuan Proposal Penegerian Madrasah. 2009, Subdit Kelembagaan dan Kerjasama Direktorat Pendidikan Madrasah. Direktorat Jenderal Pendidikan Islam Kementerian Agama RI.

Purwanti, Endang. 2008. Asesmen Pembelajaran SD. Jakarta: Direktorat Jendral Pendidikan Tinggi Departemen Pendidikan Nasional.

Singarimbun, Masri, 1995. Metode Penelitian Survai, Jakarta: PT Pustaka LP3ES Indonesia.

Supiana. 2008. Sistem Pendidikan Madrasah Unggul. Jakarta: Badan Litbang dan Diklat Kementeria Agam RI.

Syaikhu Usman. 2014. Metode Evaluasi Pelaksanaan Kebijakan. Jakarta: Lembaga Penelitian SMERU .

Widoyoko, S. Eko Putro. 2012. Evaluasi Program Pembelajaran. Yogyakarta: Pustaka Pelajar. 